\title{
HUBUNGAN KEPATUHAN MINUM OBAT DENGAN KESEMBUHAN PASIEN TUBERKULOSIS PARU BTA POSITIF DI PUSKESMAS DELANGGU KABUPATEN KLATEN
}

\author{
Aris Widiyanto \\ Akper Mamba'ul 'Ulum Surakarta
}

\begin{abstract}
Compliance Take Medicine The, Recovering, Positive Tuberkulosis TB lung $\boldsymbol{B T A}$. Object This research is know the relationship of among compliance take medicine recoveredly is patient of positive TB lung BTA in Puskesmas Delanggu of Sub-Province Klaten. Method this is analytic observational with the approach of research of cross sectional. Sample in this research is patient of positive TB lung BTA which is registered in register TB Puskesmas Delanggu in the year 2012 which have followed the program DOTS and have finished its medication in the year 2013. Technique of Intake sample in this research is random sampling by sample counted 38 respondent. Technique analysis in this research is Chi Square. Patient TB in Puskesmas Delanggu Klaten most obedient take medicine counted 25 responder $(65,8 \%)$ and recovering of positive patient TB BTA most recovering counted 32 responder (84,2\%). There are relationship between compliance take medicine recoveredly is positive patient TB BTA in Puskesmas Delanggu Klaten. This Matter proven by value significant $(P) 0.006$ by $=5 \%$ hence $P<$ 0.05. Compliance take medicine to influence the storey recovering of positive patient TB BTA in Puskesmas Delanggu Klaten.
\end{abstract}

Keywords: Compliance Take Medicine The, Recovering, Positive Tuberkulosis TB lung BTA

Abstrak: Kepatuhan Minum Obat, Kesembuhan, Tuberkulosis TB Paru Positif BTA. Tujuan penelitian ini adalah mengetahui hubungan antara kepatuhan minum obat dengan kesembuhan pasien TB paru BTA positif di Puskesmas Delanggu Kabupaten Klaten. Metode penelitian ini adalah observasional analitik dengan pendekatan penelitian cross sectional. Sampel dalam penelitian ini adalah pasien TB paru BTA positif yang tercatat dalam register TB puskesmas Delanggu pada tahun 2012 yang telah mengikuti program DOTS dan telah menyelesaikan pengobatannya pada tahun 2013. Teknik pengambilan sampel dalam penelitian ini adalah ramdom sampling dengan sampel sebanyak 38 responden. Teknik analisis dalam penelitian ini adalah Chi Square. Hasil penelitian: Pasien TB di Puskesmas Delanggu Klaten sebagian besar patuh minum obat sebanyak 25 responden $(65,8 \%)$ dan kesembuhan pasien TB BTA positif sebagian besar sembuh sebanyak 32 responden $(84,2 \%)$. Ada hubungan antara kepatuhan minum obat dengan kesembuhan pasien TB BTA positif di Puskesmas Delanggu Klaten. Hal ini terbukti dengan nilai signifikansi $(P) 0.006$ dengan $(\alpha)=5 \%$ maka $P<0.05$. Kepatuhan minum obat mempengaruhi tingkat kesembuhan pasien TB BTA positif di Puskesmas Delanggu Klaten.

Kata Kunci : Kepatuhan Minum Obat, Kesembuhan, Tuberkulosis TB Paru Positif BTA 


\section{PENDAHULUAN}

Tuberkulosis atau TB adalah penyakit menular yang disebabkan oleh Mycobacterium tuberculose yang merupakan bakteri tahan asam (BTA). TB masih merupakan masalah kesehatan di dunia. Menurut laporan World Health Organization (WHO) tahun 2012, sebanyak 8,6 juta orang telah terinfeksi TB dan 1,3 juta orang meninggal karena TB. Secara nasional, target untuk penemuan kasus baru TB paru BTA positif adalah $70 \%$. Tetapi di Jawa Tengah, target ini belum terpenuhi. Dari tahun 2010 sampai dengan tahun 2012, penemuan kasus baru BTA positif (case detection rate/ CDR) berkisar pada angka $59 \%$. Sedangkan untuk angka kesembuhan (cure rate) di Jawa Tengah pada tahun 2011 mengalami penurunan bila dibandingkan tahun 2010 yaitu dari $85,15 \%$ menjadi $82,50 \%$. Semakin menurun pada tahun 2012 yaitu 81,46\% . Angka tersebut masih dibawah target nasional yaitu sebesar $85 \%$. Di Kabupaten Klaten juga terjadi penurunan angka kesembuhan. Pada tahun 2013 pada tribulan I, angka kesembuhan mencapai 93\% tetapi menurun pada tribulan II yaitu $86 \%$ dan semakin menurun pada tribulan III menjadi $82 \%$.

Penderita TB tentu merupakan beban baik secara ekonomi maupun psikologis bagi keluarganya. Diperkirakan seorang pasien TB dewasaakan kehilangan rata-rata waktu kerjanya 3 sampai 4 bulan. Hal tersebut berakibat pada kehilangan pendapatan tahunan rumah tangganya sekitar 20-30\% (Depkes RI, 2007). Selain itu, pada pasien TB yang tidak dapat menyelesaikan pengobatannya secara tuntas maka resiko terjadi resistensi kuman TB terhadap obat TB semakin besar. Sehingga dapat terjadi kasus TB kebal obat atau TB MDR (multy drug resistant) dan apabila oarang lain tertular maka akan mengalami resistensi yang sama (Depkes RI, 2007). Dengan kondisi pasien TB di Kabupaten Klaten pada tahun 2013 yang banyak diderita oleh usia produktif (usia 25-44 tahun) yaitu sebesar $36,94 \%$ atau sebanyak 232 kasus dan angka kesembuhan yang menurun maka masih merupakan masalah yang perlu diteliti.

Kesembuhan pasien TB dipengaruhi oleh beberapa faktor, diantaranya adalah umur, tingkat pendidikan, status gizi, faktor lingkungan dan kepatuhan pasien dalam minum obat. Umur berhubungan dengan metabolisme tubuh termasuk dalam proses penyerapan obat. Semakin tua, maka proses metabolisme akan semakin menurun. Sedangkan pendidikan merupaka salah satu dari faktor eksternal yang mempengaruhi kesehatan seseorang. Pada orang dengan tingkat pendidikan tinggi biasanya bertindak lebih preventif pada suatu penyakit. Untuk status gizi, pada orang dengan berat badan kurang akan mempunyai risiko terhadap penyakit infeksi, sementara orang yang mempunyai berat badan di atas ukuran normal akan mempunyai risiko penyakit degeneratif (Supriasa dkk, 2002). Kondisi lingkungan yang meningkatkan risiko penyakit $\mathrm{TB}$ adalah kondisi lingkungan yang lembab karena kuman TB berkembangbiak dengan baik pada lingkungan gelap dan lembab. Faktor pengaruh yang terbesar dalam kesembuhan pasien $\mathrm{TB}$ adalah kepatuhan minum obat. Kepatuhan ini diartikan sebagai perilaku pasien untuk minum obat sesuai dengan jenis, dosis, cara minum, waktu minum dan jumlah 
hari minum obat yang sesuai dengan pedoman nasional penanggulangan TB. Hal ini belum banyak diteliti sehingga masih merupakan masalah yang harus diteliti.

Pasien TB yang minum obat secara teratur dapat menurunkan risiko 3,76 kali kegagalan pengobatan TB dibandingkan dengan pasien TB yang minum obat tidak teratur (Nugroho, 2009). Apabila pasien TB minum obat secara teratur dalam jangka waktu 2 minggu, kuman TB sudah terpecah dan tidak potensial untuk menular. Maka manfaat dari penelitian ini, jika kepatuhan minum obat tinggi maka kesembuhan pasien TB paru BTA positif juga meningkat, sehingga risiko untuk terjadi kasus TB resisten obat juga dapat dicegah. Produktivitas pasien TB juga dapat meningkat karena pasien TB yang telah minum obat secara teratur mengurangi tingkat keparahan penyakit karena TB dan apabila memerlukan rawat inap maka dapat diminimalkan jumlah hari rawat inapnya.

\section{METODE PENELITIAN}

Jenis penelitian yang digunakan adalah observasional analitik dengan pendekatan cross sectional. Lokasi penelitian di wilayah puskesmas Delanggu Kabupaten Klaten. Populasi dalam penelitian ini adalah pasien TB paru BTA positif yang tercatat dalam register TB puskesmas Delanggu. Pengambilan sampel menggunakan teknik purposive random sampling. Sampel dalam penelitian ini sebanyak 38 responden. Teknik analisis dalam penelitian ini adalah korelasi product moment dengan menggunakan bantuan program SPSS versi 20,00 for windows.

\section{HASIL PENELITIAN}

\section{Tabel 1}

Distribusi Frekuensi Responden Berdasarkan Kepatuhan Minum Obat

\begin{tabular}{lll}
\hline Pengetahuan & Frekuensi & $(\%)$ \\
\hline Baik & 13 & 34,2 \\
Kurang & 25 & 65,8 \\
\hline Jumlah & 38 & 100 \\
\hline
\end{tabular}

Berdasarkan tabel di atas diketahui bahwa responden yang patuh minum obat tergolong baik sebesar 13 responden $(34,2 \%)$ dan kepatuhan minum obat yang tergolong kurang sebanyak 25 responden $(65,8 \%)$. Hasil data penelitian ini menunjukkan pasien TB paru BTA positif yang tercatat dalam register TB puskesmas Delanggu pada tahun 2012 yang telah mengikuti program DOTS dan telah menyelesaikan pengobatannya.

Tabel 2

Distribusi Frekuensi Responden

Berdasarkan Kesembuhan Pasien TB Paru BTA Positif

\begin{tabular}{lll}
\hline Kesembuhan & Frekuensi & $(\%)$ \\
\hline Tidak sembuh & 6 & 15,8 \\
Sembuh & 32 & 84,2 \\
\hline Jumlah & 38 & 100 \\
\hline
\end{tabular}

Berdasarkan tabel di atas diketahui bahwa sebagian besar ibu usia menopause jarang merasa cemas sebanyak 29 responden $(74,4 \%)$, ibu usia menopause yang tidak cemas sebesar 3 responden $(7,7 \%)$, kadang-kadang cemas 3 responden $(7,7 \%)$, dan ibu yang sering merasa cemas 4 responden $(10,3 \%)$. Hasil data penelitian ini menunjukkan pasien TB paru BTA positif yang tercatat dalam register TB puskesmas Delanggu pada tahun 2012 yang telah mengikuti program DOTS dan telah menyelesaikan pengobatannya. 
Tabel 3

\section{Hubungan Kepatuhan Minum Obat dengan Kesembuhan Pasien Tuberkulosis BTA Positif}

\begin{tabular}{ccccccc}
\hline \multirow{2}{*}{ Variabel } & \multicolumn{2}{c}{ Kesembuhan } & & & \\
\cline { 2 - 5 } & $\begin{array}{c}\text { Tidak } \\
\text { sembuh }\end{array}$ & Sembuh & Jml & $\chi^{2}$ & Pvalue \\
\hline \multirow{2}{*}{ Kepatuhan } & $\begin{array}{c}\text { Tidak } \\
\text { patuh }\end{array}$ & 5 & 8 & 13 & 7.639 & 0.006 \\
& Patuh & 1 & 24 & 25 & & \\
\hline \multicolumn{2}{c}{ Jumlah } & 6 & 32 & 38 & & \\
\hline
\end{tabular}

Berdasarkan hasil analisis uji Chi

Square dengan dibantu menggunakan program SPSS 21.00 diperoleh hasil $\chi$ 2hitung sebesar 7,639, sehingga dibandingkan $\chi 2$ hitung $>\chi 2$ tabel atau nilai signifikansi (P) 0.006 dengan alpha $=5 \%$ maka $\mathrm{P}<0.05$, maka Ho ditolak artinya ada hubungan kepatuhan minum obat dengan kesembuhan pasien tuberkulosis BTA positif di Puskesmas Delanggu Kabupaten Klaten. Hal ini menunjukkan apabila pasien TB minum obat secara teratur maka tingkat kesembuhan pasien TB paru juga meningkat.

Berdasarkan tabulasi silang di atas menunjukkan bahwa pasien TB paru yang tidak patuh minum obat sebanyak 13 responden, 5 responden di antaranya tidak sembuh dan 8 responden sembuh. Responden yangg patuh minum obat sebanyak 25 responden dan hanya 1 responden di antaranya tidak sembuh.

\section{PEMBAHASAN}

Hasil penelitian tentang kepatuhan minum obat pasien tuberkulosis di Puskesmas Delanggu Klaten sebagian besar termasuk kategori patuh yaitu 25 responden $(65,8 \%)$. Kepatuhan penderita dipengaruhi oleh kemauan dan motivasi diri untuk sembuh. Hal ini dapat dimungkinkan responden sudah mengerti dan memahami tentang penyakit tuberkulosis sehingga responden minum obat sesuai dengan jenis, dosis, cara minum, waktu minum dan jumlah hari minum obat yang sesuai dianjurkan oleh dokter. Kepatuhan pengobatan TB merupakan hal yang sangat penting, karena bila pengobatan tidak dilakukan secara teratur dan tidak sesuai dengan waktu yang telah ditentukan maka akan dapat timbul kekebalan kuman TB terhadap Obat Anti TB (OAT) secara meluas atau disebut Multi Drugs Resistance (MDR). Umumnya penderita minum obat selama 6 bulan untuk memastikan kesembuhannya, namun pada beberapa keadaan dapat lebih lama (DepKes RI, 2006).

Hasil penelitian menunjukkan sebanyak 13 responden $(34,2 \%)$ tidak patuh minum obat. Hal ini dapat dimungkinkan penderita yang mulai bosan dengan pengobatan yang berjangka panjang dan kurangnya pengetahuan efek dari pengobatan yang tidak patuh yang akan sulit untuk diobati. Selain itu adanya riwayat penyakit lain yang mengharuskan pasien meminum obat menyebabkan pasien harus meminum berbagai jenis obat dalam waktu yang bersamaan atau berbeda-beda tiap harinya. Banyaknya obat yang harus diminum serta aturan pakai obat yang berbeda-beda dapat membuat pasien merasa bingung dan jenuh sehingga berpotensi terhadap ketidakpatuhan terhadap pengobatan (Hayati, 2011).

Hasil penelitian tentang kesembuhan pasien TB paru BTA positif di Puskesmas Delanggu Klaten sebagian besar sembuh yaitu sebanyak 32 responden $(84,2 \%)$. Hal ini menunjukkan bahwa responden sudah menyadari betapa bahayanya penyakit tuberkulosis kalau tidak diobati, responden sudah mengetahui dan memahami penularan 
tuberkulosis jika segera tidak ditangani. Maka dari itu responden berantusias untuk melakukan pengobatan supaya sembuh dari tuberkulosis. Kesembuhan pasien TB dipengaruhi oleh beberapa faktor, diantaranya adalah umur, tingkat pendidikan, status gizi, faktor lingkungan dan kepatuhan pasien dalam minum obat. Umur berhubungan dengan metabolisme tubuh termasuk dalam proses penyerapan obat. Semakin tua, maka proses metabolisme akan semakin menurun. Sedangkan pendidikan merupaka salah satu dari faktor eksternal yang mempengaruhi kesehatan seseorang. Pada orang dengan tingkat pendidikan tinggi biasanya bertindak lebih preventif pada suatu penyakit. Hal ini bisa dilihat sebagian besar responden berpendidikan SMA. Pendidikan merupakan salah satu dari faktor eksternal yang mempengaruhi kesehatan seseorang. Pada orang dengan tingkat pendidikan tinggi biasanya bertindak lebih preventif pada suatu penyakit. Semakin tinggi tingkat pendidikan pasien, maka semakin baik penerimaan nformasi tentang pengobatan yang diterimanya sehingga pasien akan patuh dalam pengobatan penyakitnya (Munro dalam Pasek, 2013).

Hasil penelitian menunjukkan 6 responden $(15,6 \%)$ tidak sembuh. Hal ini dapat disebabkan kurang patuhnya responden dalam meminum obat tuberkulosis, selain itu tingkat penghasilan seseorang sangat mempengaruhi pasien untuk melakukan pengobatan tuberkulosis. Sebagian besar pekerjaan responden adalah buruh, petani dan swasta. Dengan terbatasnya keadaan ekonomi mengakibatkan pasien tidak melanjutkan pengobatan rutin ke balai pengobatan sehingga hal ini mendorong tingkat kesembuhan penyakit pasien.
Kegagalan dalam pengobatan TB paru disebabkan oleh berbagai faktor, salah satunya adalah tingkat pendapatan (Safri, 2013).

Berdasarkan uji Chi Square bahwa nilai signifikansi $(\mathrm{P}) 0.006$ dengan $(\alpha)=$ $5 \%$ maka $\mathrm{P}<0.05$, maka Ho ditolak artinya ada hubungan kepatuhan minum obat dengan kesembbuhan pasien tuberkulosis paru BTA positif di Puskesmas Delanggu Kabupaten Klaten. Kesembuhan pasien juga tergantung pada kepatuhan pasien minum obat. Kepatuhan minum obat pada pengobatan tuberkulosis sangat penting karena dengan minum obat secara teratur dalam jangka waktu 2 minggu, kuman TB sudah terpecah dan tidak potensial untuk menular. Sehingga dapat disimpulkan bahwa jika kepatuhan minum obat tinggi maka kesembuhan pasien TB paru BTA positif juga meningkat, sehingga risiko untuk terjadi kasus TB resisten obat juga dapat dicegah.

Hal ini didukung oleh penelitian Puri (2010) pasien TB paru kasus baru dengan kinerja PMO baik lebih besar kemungkinan untuk dapat sembuh. Pada kelompok yang menerapkan strategi DOTS dengan pengawasan oleh PMO, angka putus berobat cenderung lebih rendah sehingga penderita TB paru memperoleh kesembuhan total.

Hasil penelitian ini sesuai dengan penelitian Joko Prasetyo (2009) menunjukkan secara statistik dapat dikatakan ada hubungan yang bermakna antara motivasi pasien TB Paru dengan kepatuhan dalam program pengobatan, antara yang patuh dan tidak patuh dengan signifikansi $(p$ value $)=0,0001$, alpha $=$ 0,05 . Motivasi merupakan kunci menuju keberhasilan semakin tinggi motivasi maka akan semakin patuh, dalam hal ini adalah kepatuhan meminum obat dalam 
mengikuti program pengobatan sistem DOTS.

\section{KESIMPULAN DAN SARAN}

Pasien TB di Puskesmas Delanggu Klaten sebagian besar patuh minum obat sebanyak 25 responden $(65,8 \%)$ dan kesembuhan pasien TB BTA positif sebagian besar sembuh sebanyak 32 responden $(84,2 \%)$.

Ada hubungan antara kepatuhan minum obat dengan kesembuhan pasien TB BTA positif di Puskesmas Delanggu Klaten. Hal ini terbukti dengan nilai signifikansi $(P) 0.006$ dengan $(\alpha)=5 \%$ maka $\mathrm{P}<0.05$.

Diharapkan hasil penelitian dapat memberikan informasi tentang karakteristik dan kepatuhan pasien minum obat yang berhubungan dengan keberhasilan pengobatan pasien TB di Kabupaten Klaten sehingga pengetahuan masyarakat tentang penyakit dan pengobatan TB bagi penderita TB akan meningkat. Semoga hasil penelitian ini dapat memberikan masukan dan dasar untuk pengambilan keputusan dalam rangka meningkatkan upaya-upaya penanggulangan TB. Semoga hasil penelitian ini dapat dijadikan tambahan referensi untuk penelitian selanjutnya dengan menambah faktor-fakttor yang mempengaruhi kesembuhan pasien TB BTA positif

\section{DAFTAR RUJUKAN}

DepKes RI. $2006 . \quad$ Pedoman Penanggulangan Tuberkulosis. Jakarta: Depkes RI.

Hayati, Armelia, 2011. Evaluasi Kepatuhan Berobat Penderita Tuberkulosis Paru Tahun 2010 2011 di Puskesmas Kecamatan Pancoran Mas Depok. Jakarta:
Fakultas Ilmu Matematika dan IPA Departemen Farmasi.

Nugroho, B. 2009. Faktor-Faktor Risiko Yang Mempengaruhi Kegagalan Pengobatan Pada Penderita Tuberkulosis Paru Dengan Strategi DOTS (Studi Kasus di BP4 Pati). Tesis. Diunduh tanggal 2 Februari 2011 dari http://eprints.undip.ac.id/4441/

Pasek, Made Sudnyani. 2013. Hubungan Persepsi dan Tingkat Pengetahuan Penderita Tuberkulosis Dengan Kepatuhan Pengobatan di Wilayah Kerja Puskesmas Buleleng 1. Jurnal Magister Kedokteran Keluarga Vol 1. No. 1.

Puri, Nomi Andika.2010. Hubungan Kinerja Pengawas Minum Obat (PMO) Dengan Kesembuhan Pasien TB Paru Kasus Baru Strategi DOTS. Surakarta: Fakultas Kedokteran UNS.

Safri, Firman Maulana. 2013. Analisis Faktor Yang Berhubungan Dengan Kepatuhan Minum Obat Pasien Tb Paru Berdasarkan Health Belief Model di Wilayah Kerja Puskesmas Umbulsari, Kabupaten Jember. Surabaya: Fakultas Keperawatan Universitas Airlangga 